\title{
Women and Religion in Contemporary Taiwan
}

\author{
Ming-Yeung Cheung*
}

\begin{abstract}
Religion in general, and Christianity in particular, plays an ambiguous role in the issue of gender equality and women's rights in Taiwan. While women are very often marginalized in traditional culture, religious reasons are also often used to reenforce gender inequality and discrimination in confirming the traditional gender roles in the family and religious institutions. However, religion is also a force for liberation of marginalized women in the work of some scholar-activists of religion and theology who struggle for gender justice. This article aims, on the one hand, to let the reader have a glimpse of the situation of women in Taiwan as reflected in these authors' works, and, on the other hand, to show how they draw resources from religion and work for the rights and liberation of women in their society, through their advocacy and discussions on issues such as sexism, divorce and abortion.
\end{abstract}

Key words: women; Taiwan christianity; tradition; liberation; sexism; divorce; abortion.

\section{Mulheres e Religião na Taiwan Contemporânea}

\section{Resumo}

A religião em geral, e o cristianismo em particular, desempenha um papel ambíguo na questão da igualdade de gênero e dos direitos das mulheres em Taiwan. Embora as mulheres sejam muitas vezes marginalizadas na cultura tradicional, as razões religiosas também são usadas com frequência para reforçar a desigualdade e a discriminação de gênero, confirmando os papéis tradicionais de gênero nas instituições familiares e religiosas. No entanto, a religião é também uma força para a libertação de mulheres marginalizadas no trabalho de alguns acadêmicos-ativistas de religião e de teologia que lutam pela igualdade de gênero. Este artigo visa, por um lado, deixar que o leitor tenha um vislumbre da situação das mulheres em Taiwan, conforme refletido nos trabalhos desses autores, e, por outro lado, mostrar como elas extraem recursos da religião e trabalham pelos direitos e libertação das mulheres na sua sociedade, através da sua defesa de direitos e discussões sobre questões como sexismo, divórcio e aborto.

Palavras-chave: mulheres; cristianismo em Taiwan; tradição; libertação; sexismo; divórcio; aborto.

* Fu Jen Catholic University 


\section{Mujeres y religión en el Taiwán contemporáneo}

\section{Resumen}

La religión en general, y el cristianismo en particular, desempeñan un papel ambiguo en el tema de la igualdad de género y los derechos de las mujeres en Taiwán. Si bien las mujeres a menudo están marginadas en la cultura tradicional, las razones religiosas también se usan para reforzar la desigualdad de género y la discriminación, para así confirmar los roles de género tradicionales en la familia y en las instituciones religiosas. Sin embargo, la religión también es una fuerza para la liberación de mujeres marginadas en el trabajo de algunos eruditos-activistas de la religión y la teología que luchan por la justicia de género. El objetivo de este artículo es, por un lado, permitir que el lector pueda vislumbrar la situación de las mujeres en Taiwán como se refleja en los trabajos de estos autores y, por otro lado, mostrar cómo obtienen recursos de la religión y trabajan por los derechos y la liberación de las mujeres en su sociedad, a través de su defensa y discusiones sobre temas como el sexismo, el divorcio y el aborto.

Palabras clave: mujeres; cristianismo taiwanés; tradición; liberación; sexismo; divorcio; aborto.

In this article, I will report on issues regarding religion and women as the marginalized in Taiwan through introducing the works of several scholaractivists of religion and theology who are concerned with women's rights. My purpose is twofold: to let the reader have a glimpse of the situation of women as marginalized in Taiwan as reflected in these authors' works, and to show how Taiwanese women scholars of religions work for the rights and liberation of women in their society, both in and outside the Christian church setting.

The main author that I will introduce is Hannah Chen, who teaches in the Yu-shan Theological College and Seminary, a Christian seminary for Taiwanese indigenous people. Besides academic articles, she writes a lot for the general public and Christian laypersons, so many of her works appear in daily newspapers as well as Christian magazines. She regularly publishes books collecting her dispersed writings which appeared across different media during the previous year(s).

Chen reports on and involves in the discussions among Taiwan Christians around the issue of abortion, divorce and sexual harassment, as well as capital punishment, disabilities, and sexual minority, including the so-called "equal rights movement" concerning the rights to marriage. 


\section{Women as the Marginalized}

The situation of Taiwanese women may be reflected in the divorce law and the attitude of the Taiwanese church ${ }^{1}$ as described in Chen's article about divorce. When a Christian couple undergo a crisis in their marriage, to avoid a divorce, the pastors will either ask the wife to "just submit to the husband and let go of the sin of pride and self-righteousness", or ask the couple "to continue the unhappy marriage, without providing any effective counseling" (CHEN, 2002, p. 3) 3 . For Chen, this is in line with the conservative attitude of the Western and even worldwide Christian churches.

Chen agrees with another feminist Protestant scholar and educator Kao Tien-Hsiang of a generation earlier (actively teaching and writing during 1980s-2000s) that "from ancient times until today [sic], the society has been and is a society in which men have the power to take away or spare women's lives, and will sell or betray women if necessary" (CHEN, 2017, p. 60) ${ }^{4}$. Kao claims that this is the reason why there are so many cases of killing of baby girls, of kidnapping and trafficking of women, and of sexual aggression in the society. Chen and Kao both want to encourage the local feminist theological movement to move beyond the boundaries of the faith community and seek for social justice. In Chen's words, Taiwanese feminist theological movement should "make the society which betrays women repent and confess its sin through [listening to] the accusation of the wronged ghosts" $\left(2017\right.$, p. 60) ${ }^{5}$. Kao thinks that this listening to the historical voices can serve three purposes. First, it starts the healing process; second, it deepens the understanding of women's dire situation and the origin of their oppression; third, it helps to find the direction of struggling for women's right and dignity (KAO, 2008, p. 141, quoted in CHEN, 2017, p. 60).

Women's situation in Taiwan may also be seen by reading Chen's report and discussion around the "abortion controversy" in Taiwan. In an article originally published in 2001, Chen comments on the situation of Taiwanese women with respect to "giving birth and nurturing" (the literal meaning of the Chinese term for reproduction, shengyu).

1 In Chen's article, her criticism of the church applies to both Protestant and Catholic churches, although in some places she names the specific Christian tradition that she is talking about.

2 “一味順服自己的丈夫, 離棄驕傲、自高自大的罪”. This and all subsequent quotations from Chen's work are my translations, unless otherwise stated.

“繼續不愉快的婚姻，卻沒有提供任何有效的輔導措施”.

“從古至今的社會是一個男人執掌女性的生殺大權，甚至不惜出賣女性的社會”.

“讓出賣女性的社會可以透過冤魂的控訴而悔改認罪”. 
In the article, she rejects the dichotomy of "pro-choice" or "prolife". For her, disagreeing with the so-called "pro-life" argument does not automatically imply a stance of "pro-choice" on the debate about abortion. In Taiwanese culture, women's personal choice is never given priority in decision about their lives, especially in the matter of reproduction. If a woman has not given birth to a son (even though she may have many daughters), she is as good (or bad) as someone who is sterile. The patriarchal exploitation of the female body is reflected in families, for example, in which "the smallest child is a boy with seven elder sisters" ${ }^{\text {, }}$ or in girls who are named "Bring-aBrother", "Daughter-Final"", etc. Moreover, in Taiwanese law (as in 2002), it is stated that even "when pregnancy may bring risk to life, or may be detrimental to physical or mental health, induced miscarriage may be carried out at [the pregnant women's] request only after having the consent of her spouse" (This law has been revised later so that the consent of one's spouse is no longer necessary. Quoted in CHEN 2002, p. 149) ${ }^{8}$.

Taiwanese Women's socio-cultural status is also reflected in the gender construction in traditional custom. To illustrate this, Chen recounts, in another article, one example of Taiwanese custom: the postpartum confinement, literally "sitting-the-month" or "doing-the-month" (Chen, 2005, pp. 14-16) ${ }^{9}$. After giving birth, women are required to minimize activities, refrain from going out. During the month of confinement, they should not even take bath or wash their hair. Most of the time, a woman who has given birth to a boy will receive a much better treatment than if she gives birth to a girl. Only after giving birth to a son may a woman be accepted officially into her husband's (extended) family and thus establish her social status within and without the extended family. The ritual and taboo related to this custom reflect the gender construction of a patriarchal culture in which the husband or the father has much power over a woman's life. If a woman is treated well by her husband's family, she will be respected by other women (especially those in the neighborhood, who form her closest social circle); if not, she will be despised.

\footnotetext{
6 “七仙女加上「弟”.

Examples of girls” names are “招弟” and “金滿” (the English translations are mine). “懷孕會招致生命危險, 或危害身體或精种健康者, 都需徵得其配偶同意, 始得依 其自願實施人工流「”。

9 “坐月子” or “作月內”.
} 
Related to this custom is the taboo that during the discharge of lochia, a woman is considered "unclean" and no one should be in contact with her except the closest family members. According to this taboo, she would bring misfortune to herself and others if she visits anyone during this period. Although there are some medical or health reasons behind this custom, Chen argues that its ritual is more related to cultural and social custom rather than physical need, citing the custom of "couvade" (a reversal of the roles of man and woman in a similar postpartum confinement) in some South American Indian culture.

In citing this example, Chen's purpose is to promote a change in the customs with both local resources and the efforts from Western feminist theologians. For the deconstruction-reconstruction of the customary ritual, she takes the clue from the girls' puberty rite in Rosemary Radford Ruether's Women-Church: Theology and Practice of Feminist Liturgical Communities ${ }^{10}$ and suggests that the churches in Taiwan may create new ritual by both taking the diverse local culture seriously and reflecting critically if they have aided in the liberation of women from gender oppression. For Chen, changing the mythical/ritual thinking and practice is an important work that feminist theology and the local women's right movement should develop alongside rational arguments in the areas of law, economics and politics/policies (2002, pp. 19-21).

\section{Lack of Concern for Women's Welfare in the Abortion Debate}

According to Chen (2017, p. 48), from 1998 to 2008, during a decade of advocation to revise the Act of Reproductive Health ${ }^{11}$, the effort of the women's groups in Taiwan was under attack and suppression from patriarchal religious groups, led by Christian groups. The major issues involved include: Should the assent of the husband be required for a woman to have abortion? If not, should there be a "period of reflection" before the execution (and if so, how long)? Should a parent be required to be present if a girl under the legal age seeks abortion, or should a certified social worker or a relative be adequate?

My discussion of Chen's argument on this controversy is not to have a detailed examination of arguments for or against abortion, but to highlight

\footnotetext{
10 Published in San Francisco by Harper \& Row in 1985.

11 “生育保健法”. This is not the current Chinese title of the Act. The use of this title in Chen's article is perhaps to show her sympathy with the suggested revision to this Act, including the Chinese title. See discussions below.
} 
the lack of concern for the welfare and rights of women in the mainstream culture in Taiwan as reflected in the arguments against abortion and for the removal of a paragraph in the so-called "abortion law" that states if "pregnancy or childbirth is likely to affect her mental health or family life," it is a legitimate reason for a woman to request abortion (Paragraph 6, Article 9 of the Genetic Health Act) ${ }^{12}$.

Genetic Health Act was the official English title given on the government's website, but actually as I am writing this article, the Chinese title of the Act uses the term "yousheng" (literally improvement of life), which is usually used to translate the term "eugenics". Recently, some legislators are proposing to rename it as "shengyu" which means "reproduction", arguing that the term "yousheng" is biased against people with disabilities 13 .

According to Chen, the controversy, sometimes described as a war/ struggle between women's rights and faith, was raised by Taiwanese Catholic, Protestant and other religious communities. The conservative "moralitydefending" groups linked and united with each other in action. In 2002, an anti-abortion group, Alliance for the Respect of $\mathrm{Life}^{14}$, was formed. It aims at reverting the abortion right through political acts of lobbying, mass movement, and law revision. Chen claims that this was the first movement of the local religious right in Taiwan (CHEN, 2017, p. 49). The Research Center for Bioethics of the Fu Jen Catholic University took a leading role. It sent The Eclipse of Reason, an anti-abortion film, in video CD format, to many different groups including high schools. It also hoped to reduce or even eliminate the so-called "September abortion wave"15. The Alliance would play an important role in the subsequent "clashes/encounters" between faith and social gender equality movement, such as legislation against sexual orientation discrimination, same-sex marriage, and the education of gender equality.

Chen tries to help Taiwanese (at least Christians) to understand the controversy about abortion by tracing it back to the teachings about the

12 Genetic Health Act, in Laws \& Regulations Database of The Republic of China. Available at: https://law.moj.gov.tw/ENG/LawClass/LawAll.aspx?PCode=L0070001 . Accessed on: 30, Sep., 2018.

13 Legislative Yuan member's proposal no. 21788. Available at: https://lci.ly.gov.tw/ LyLCEW/agenda1/02/pdf/09/05/07/LCEWA01_090507_00021.pdf . Accessed on: 1, Oct., 2018.

14 “學重生命大聯盟”.

15 “九月隋胎潮”. It is said to be the result of many youth having sex without birth control during the summer vacation. 
moral status of the embryo by the Roman Catholic church (CHEN, 2017, p. 50). She points out that the basis for the "moral dignity of the embryo" claimed by the Declaration on Procured Abortion (Vatican, 1974) is based on an essentialist approach, appealing to the research results of genetics. In this view, all the subsequent development (of the embryo) is determined by the "genes", which are like a "book of life". Chen questions this view from the perspective of bioethics. She points out that the essentialist approach combines the Aristotelian metaphysical assumptions, such as the notions of potentiality and actuality, with contemporary genetics in a simplistic way.

Chen's argument is based on functionalist feminist bioethics ${ }^{16}$. In this view, the mother is not only a "container" of the embryo. There is a change of the significance of the relationship between the mother and the embryo/child in different stages of the pregnancy ${ }^{17}$. Chen points out that, according to recent discoveries in embryonic evolution research, in the early stage, the embryo may develop into dual or multiple embryos, and later could even join together into conjoined twins, and even more, one of them may be absorbed by the other and become part of the body. Depending on the environment and hormonic influence by the mother, the embryo may exhibit female physicality with male genes, or vice versa, or it may possess physical characteristics of both sexes (CHEN, 2017, p. 51).

Besides challenging the essentialist view on the status of the embryo, Chen points out that since women do not have any legal control over their own bodies, they are subjected to the will of their fathers and husbands. This is evident in the fact that abortions are permitted only when they are in the interest of the patriarchal society, for example, in cases of genetically inherited diseases, fetus deformation, or rape, and when it is harmful to family life (legal abortion for teenagers must be accompanied by parents). In parallel to a biblical saying, she says, "If you cannot love the women you can see, why talk pretentiously about the fetus that you cannot see?!" (CHEN, 2002, p. 149) ${ }^{18}$.

With the example of Sweden, Chen argues that a better protection and welfare system for women along with autonomy for women over abortion may even lower the rate of abortion for a society. Abortion, just as any

\footnotetext{
16 She adapts this view form the view of Mary Anne Warren.

17 For the differentiation of moral status within Christian tradition, see Chen's discussion in Abortion? No Abortion! Abortion! No Abortion? (2002, pp. 150-151).

18 “看得見的婦女都不愛, 又奢談看不見的胎兒？!”
} 
destruction of life, is not something desirable, and almost always cause physical or mental harm to women. However, instead of airy moral discourse, the churches should care for women in concrete acts, if they really think that abortion is an important issue in Christian social ethics. She argues that, by accusing women, who do not even have autonomy, of murder with the intention of stopping abortion, the churches have committed the faults of ignoring the concrete situation and the more fundamental task of building a society with gender justice.

She criticizes the churches of adopting only traditional ethical deduction without taking the difficult circumstances around cases of abortion into account. The discussions focus only on the "human status" of the zygote, embryo or fetus, and on legislation as a solution, while turning a blind eye to the lack of gender justice of those seeking abortion. As women, they are the underprivileged of society both economically and in emotional and sexual life. She notices that men's role in the issue is not much mentioned. Neither their role in the cause (their unwillingness of using birth control) nor in the consequence (their lack of legal obligation in the caring of the child) is considered important to the debate.

\section{Feminist Biblical Interpretation and Theology}

In Chen's interpretation of Exodus 4:24-26, she points out that a traditionally popular Chinese study Bible ${ }^{19}$ comments on these verses that "... it may have been Zipporah who had prevented the circumcision of Moses's son" (quoted in CHEN, 2017, p. 62) ${ }^{20}$. She remarks that here even when a woman is obviously someone who saves, she can be interpreted distortedly as the one who has caused the crisis, one can imagine what would be done to other verses. Instead of Moses's perspective, Chen's interpretation reads the passage from the perspective of Zipporah. When she met Moses, he appeared to her and her sisters as an "Egyptian". Moreover, when Moses left his father-in-law to go back to Egypt, he only said that he went back to see his brothers, leaving the readers to wonder if he had ever revealed his real reason for leaving Egypt and his identity as Israelite. For Chen, the description that "God wanted to kill Moses" is a metaphor for Moses's intense pain as he

\footnotetext{
19 The Chinese Study Bible (啟導本), published by the Rock House in Hong Kong. There have been many revisions of this study bible since 1989. It is not clear which revision does Chen quote from. However, there should not be much change between revisions.

20 “阻止給摩西的兒子受割禮的可能是西坡拉”.
} 
had to deal with his relationship with Zipporah, his identity and the truth of his mission. It was the wise Zipporah who realized the truth and saved Moses by her prompt action: first of all, she followed the Jewish custom of circumcising their child as an acceptance of Moses's identity; second, she used the cut foreskin of their child to touch Moses's "feet", showing her commitment to her marriage with Moses using a custom Midean wedding rite. By further recontextualizing the passage with the life stories of the wives of Taiwanese political prisoners, Chen provides a well-argued solution to the difficulties found in this passage and enriches the understanding of it.

Chen proposes that Taiwanese Protestants should adopt liberationist or feminist biblical hermeneutics. This position recognizes that traditional Christian teachings concerning sex, gender and reproduction have been a product of a patriarchal society that exerted control over women's lives. What the Protestants should do is to "empower women to properly use their productive capability" ${ }^{21}$ through "promoting a general social reform" (CHEN, 2005, p. 88) ${ }^{22}$.

Chen challenges the arguments of Taiwanese Christian anti-abortion campaign with evidences in biblical interpretations and historical evidences in theological discussions. After examining the writings of the Church Fathers on the issue, she concludes with a rhetorical question: "Abortion is certainly not good, but is it true that the Bible or church tradition teaches without discretion that, ever since the time of conception, abortion is a grave sin of murder" (Chen, 2003, p. 151) ${ }^{23}$ ?

In her discussion on the issue of abortion, Chen argues that the "less open" attitude towards sex, gender roles, marriage and family that most Protestant churches in Taiwan tend to adopt is a combined result of their historical origins in more conservative Western missionary organizations, the lack of democratic spirit and critical thinking during the rule of martial law (1949-1987), and the influence of the patriarchal family system in mainstream Confucian culture. In addition, these churches usually adopt a fundamentalist view of the Bible which does not favor the discussion of different theological views. Consequently, church ministers do not know (or want to know) about the cases of abortion among church members, as they are considered private

\footnotetext{
21 “賦權婦女適切地運用其生育能力”.

22 “推動廣泛的社會改革”.

23 “隋胎固然不好，但無論是聖經或「會傳統豈是不分「紅「白地說，從受孕那一「怄区 Q
} 
matters, without realizing the publicness of this issue. The churches only condemn personal sins, ignoring the fact that the personal choices are the results of a society without gender justice. Chen claims that the major causes of abortion cases are the lack of education about safe-sex, the imbalance of power between the sexes in romantic relationships, the refusal of men to use any birth control because of the myth of masculinity, and the timidity of women who are trained to be obedient and giving and therefore dare not raise any objection even in things that have life-long influence for them (CHEN, 2005, p. 89).

In her suggestions as to how the church face is issue of abortion, Chen proposes that the focus should shift from personal morality, immoral sexual act, criticism of women, to the structural sin of the patriarchal society; from moral accusation to encouragement, sympathy and help; from the human status of the fetus to the well-being of the mother. Moreover, the church should take into consideration of more factors which did not play any role in Bible and tradition: for example, it is recognized that the original purpose of sexual intercourse is no longer confined to procreation but the emotional communication of a man and a woman, and the progress in medical science and technology results in a better knowledge about the growth and development of the embryo/fetus as well as the possibility of detecting abnormality of the embryo at an earlier stage (CHEN, 2002, pp. 151-152).

\section{Transforming Gender Oppression: Feminist Theology of Culture}

Her experience in struggling with the issue of women's reproduction autonomy helps Chen to realize that it is necessary to look at the issue in the larger context of gender culture. In traditional culture, women often use a more pragmatic and contextual approach to thinking in contrast to (and subverting) the male-centered concept of "reason" and "autonomy". This realization led her to develop not only a theology around "women's issues" but "different theologies" of culture, with a broader local feminist liberationist horizon (CHEN, 2017, pp. 52-53).

While Chen acknowledges that legislation is and has been a effective instrument to reshape social values, she works also toward the transformation of culture within a society through the renewal of the teachings of the church (CHEN, 2017, p. 54). 
In several articles (cf. CHEN, 2017, p. 54), Chen emphasizes that since the moral discussions on the good or bad gender roles within the sexist mainstream culture is mainly manipulated by the male-centered and maleoriented power and authorities, those women who refuse to compromise have two possibilities. Either they are classified as "bad girls" or they choose to resist and laugh at the oppression imposed on them by craziness, or, after their death due to their transgression of the patriarchal boundary, they became homeless ghosts who come back from time to time to haunt the human community to accuse the unjust social structure and to get their justice back.

The body, according to Chen, is the external locale through the discipline of which the patriarchal authority internalizes its various moral controls over the female. Women's bodies start to be limited already in the infant time, and this control becomes clearer during puberty, when the body becomes gendered. While young males discover during their growing up that their bodies are useful tools to explore the world around them, females discover that they are their own enemy. Their bodies are dangerous and hence should be strictly controlled. This leads to the phenomenon that the victims of sexual aggression and harassment (by someone familiar or by stranger) would often blame themselves first. Under the male-created myth of female sexual desire, the aggression towards female body becomes a socially constructed way to show one's "maleness", and thus the victims of sex crime lose her social relationships, in additional to her body and dignity (CHEN, 2002, p. 93).

Chen argues that women experience a kind of collective social oppression comparable to the "white terror"24. Within this oppression, disguised as "protection", women are expected socially to be obedient, self-restraint and quiet. If they show any kind of emotional agitation, self-assurance, or any behavior that does not conform to the social expectations, they will be labelled as "pathetic" and sent to mental hospitals. Chen thinks that this is the reason why the self-confidence of girls is found to start declining after puberty, although during primary (elementary) school years they are as self-confident as boys. This crisis of self-identity is very similar to those black males who experience serious racial discrimination (CHEN, 2017, p. 56).

24 The term "white terror" refers to a period in Taiwan from around 1947 to 1987, during which the government suppressed political dissidents with martial law. 
While some women (mainly in the West) appeal to "crazy" or "hysterical" women as a "self-metaphor" of resistance, ${ }^{25}$ stories about female ghosts serve a similar function in Confucian cultures such as Korean or Taiwanese societies. In Korean popular shamanism, most of the participants and the priestess are women. Most ghost stories in shamanism are about females, whose torturous and bitter lives make them want to stay among the "humans" after death in order to find opportunities for revenge or venting of anger. Chen proposes that these popular stories have originally aimed at "internal colonization": a process by which the discrimination against women may be internalized and deeply planted into consciousness, to an extent that even women themselves become misogynist (CHEN, 2017, pp. 57-58).

For Chen, for a theology that to bring liberation, it must recognize that all theologies, including feminist theology, are culturally embedded. Therefore, it can criticize the patriarchal dimension of the Bible and traditional theology. However, it must also avoid absolutizing any culture. Any cultural text is "a highly gendered and politicized ideological medium" 26 and therefore "must pass through the moral test of gender justice" (CHEN, 2017, p. 58) ${ }^{27}$-- this is what she means by theology of culture (wenhua shenxue).

In her view, a theology of culture for local (Taiwanese) women should serve both a deconstructive function and a reconstructive one. And perhaps before that, this theology should first of all "accept these women as they are, and let these silenced women to speak for themselves" (CHEN, 2017, p. 58 $)^{28}$. It should then analyze and deconstruct how patriarchal culture and theology speak about and demonize the female image and criticize the ideology behind these discourses. Finally, it must aim at imagining creatively a faith community which is just with respect to gender, self-critical and open, and which can serve as a criterion to evaluate if a cultural theology is "adequate and complete" (p. 59) ${ }^{29}$.

Chen advocates and practices a strategy of "doing feminist theology of culture from the margin" 30 , a practice which "works for resistive rereading and value reversal of all texts" (p. 59) ${ }^{31}$. She hopes that in this way,

\footnotetext{
Chen's examples include the author Charlotte Perkins Gilman and Florence Nightingale.

“具有高度性別意涵的意識型態媒介”.

“接受兩性正義的倫理檢測”。

“按著這些婦女的本貌接納「們，讓這些被噤聲的婦女「自己說話”.

Chen uses English terms here in her original text.

“從邊緣來做婦女文化神學”。

“對所有文本進行抵抗性的重讀與價 怄四”.
} 
local feminist theology may develop a new path of salvation by breaking the traditional dualistic thinking of "good woman vs. bad woman".

She claims that she practices her feminist biblical interpretation as a layperson, someone who have no formal training in theology ${ }^{32}$. As a layperson, her strategy to get people with class bias to listen to her biblical interpretation is by the "quick and direct way" of reinterpreting some biblical passages that are usually considered to be very difficult (CHEN, 2017, p. 59). Therefore, in her articles of biblical interpretations, Chen points out how traditional (and especially Chinese/Taiwanese) interpretations reflect gender bias against women and hence also become oppressive tools to suppress women's autonomy, rights and position in the church (something we have seen above in her interpretation of the passage concerning Zipporah).

Chen laments that the contribution of lay women's feminist theological pursuit to the development of local feminist theology and to the gender rights in and outside of Christian churches is blocked by the classism in the churches. Besides the controversy of women's reproductive autonomy, which has ceased to be a hot issue in Taiwan since 2007, Chen believes that Taiwanese local feminist theology can also have significant contribution to debates concerning rights of sexual minorities (Cf. CHEN, 2017, pp. 65-66). She continues to do theology for the marginalized with an awareness of the context of sexual pluralism, and to try to bring these topics into mainstream Protestant theological discussion, for instance, in PCT (Presbyterian Church in Taiwan) meetings, conferences, and seminaries.

\section{A Final Short Note on Buddhism and Women's Rights}

Some of Chen's arguments against the removal of Paragraph 6, Article 9 of the Genetic Health Act and the anti-abortion camp are challenged by the Buddhist feminist scholar Shih Chao-hwei. Although Shih does not agree with some of Chen's arguments (and strategy), her response highlights, and even confirms Chen's assertion that women's rights and welfare are not given serious consideration during the abortion debate. Different from Chen, she is worried about the "disappearing daughters of Taiwan," those girls who will not be born (because of abortion) in a society that prefers male children to female ones. Women having abortion maybe because of the pressure from their husbands or the extended family of the husband (mostly parents-in-

32 She has studied philosophy in her bachelor, master's and doctoral degrees. 
law), after knowing the sex of the fetus. Some of them may even share this sexist view. Shih wants to help reduce such kind of abortion. She admits that

considering the situation of the pregnant women, I do not agree an overall legal prohibition of abortion; but seriously considering the situation of the fetus (especially the female ones), I nevertheless agree to revise the law appropriately in order to improve the phenomenon of the casual abuse of abortions (SHIH, 2004).

Shih Chao-wei is the founder of Buddhist Hongshi College in Taiwan and a professor in Hsuan Chuang University (a private university with Buddhist affiliation). She has taught Buddhist studies in several academic institutes, including Fu Jen Catholic University. She is also a social activist advocating for, among other issues, gender equality in the society as well as in Buddhism. For instance, she leads the movement for the abolition of the Eight Garudhammas, which she considers as discriminating against women. The Eight Garudhammas are eight Buddhist rules commanding that nuns have to submit to monks, for example, a nun should always greet a monk with respectful salute. In 2001, she made a public declaration and arranged a symbolic ripping of the Eight Garudhammas by believers. At the same occasion she asked Dala Lama, who was visiting Taiwan, for his support. In the preface for Hannah Chen's book (2017), Shih writes that she considers the Eight Garudhammas the root of sexism in Buddhist social structure, and therefore the first thing that needs to be challenged in the women's right movement within Buddhism. To do so, she first studies the traditional sacred scriptures of Buddhism to refute the claim that this set of rules was established by the Buddha himself. Second, she argues with Buddhist teachings and rational arguments that these rules cannot be justified either psychologically, ethically or socially (CHEN, 2017, pp. 19-20).

\section{Conclusions}

Both Shih and Chen are still actively writing for and involved in the promotion of rights of women and sexual minorities. These are the two areas in Taiwanese society in which religion is playing an ambiguous role, and it takes courage to speak against the mainstream culture. Although these two brave and academically outstanding women do not completely agree with each other, they have shown us a great example by being willing to dialogue with reason, openness and sympathy. Both also exemplify by drawing support from 
the rich resources of their respective religious traditions in their works, on the one hand, and on the other hand also being open to work together with like-minded people from another religion as well as secular/non-religious activists. In a pluralistic society like Taiwan, this cooperation crossing cultural and religious boundaries is especially important and valuable in the concern for the marginalized. In the struggle for social justice, there should be no boundaries, and each should learn from the other.

\section{References}

CHEN, H. (陳文珊). 台灣本土婦女神學初探 (Preliminary Studies in Taiwanese Local Feminist Theology). Taipei: 永望文化 (Yongwang Wenhua), 2002.

CHEN, H. 非非反叛 (Not Not Rebellious). Taipei: 永望文化 (Yongwang Wenhua), 2005.

CHEN, H. 向左走向右走 : 邁向台灣基督教的性 /別 /正義 (To the Left or to the Right: Towards Sex/Gender/Justice of Christianity in Taiwan). Taipei: Avanguard, 2017.

KAO, T-H. (高天香). 推倒隔絕的牆 (Breaking Down the Dividing Wall of Hostility). 2 Volumes. Taipei: Taiwan Theological College and Seminary, 2008.

SHIH, C-W. (釋昭慧). 揮之不去的父權夢魘——評述「優生保健法」修正案之爭議 (Patriarchal Nightmare that Persists - Comments on the Controversy of the Revision of the Genetic Health Act). 應用倫理研究通訊 (Newsletter for Research of Applied Ethics), n. 31, Aug. 2004. Available at: http://in.ncu.edu.tw/phi/NRAE/newsletter/no31/05.html . Accessed on: 23, Sept., 2018. 